УДК 551.4.013: 911.52: 574.38; DOI: 10.30970/gpc.2021.1.3461

ЗМІСТ, ІСТОРІЯ ФОРМУВАННЯ ТА МЕТОДИ ДОСЛІДЖЕНЬ ЕКОЛОГІЧНОЇ ГЕОМОРФОМЕТРІї

\title{
Олександр Мкртчян
}

Львівський начіональний університет імені Івана Франка, alemkrt@gmail.com; orcid.org/0000-0002-3496-0435

Анотація. Проаналізовано екологічну морфометрію як науковий напрям, що передбачає дослідження методами кількісного просторового аналізу ролі рельєфу та процесів сучасного морфогенезу земної поверхні у функціонуванні інших складових довкілля, екосистем та у формуванні умов життєдіяльності людини. Розглянуто окремі термінологічні моменти, коротку історію геоморфометрії, основні методи ії̈ досліджень і завдання, які вона вирішує. Зокрема, розглянуто методи кількісного аналізу структури поверхонь рельєфу - виявлення просторових трендів, ритмічності, автокорельованості поверхні. Показано можливості методу побудови й аналізу автоваріограм у дослідженні елементів, форм та типів рельєфу, їхньому автоматизованому виділенні та класифікації. Розглянуто основи екологічно орієнтованої систематизації морфометричних величин, принципи виділення комплексних морфометричних величин (топографо-екологічних індексів), які відображають вплив морфології рельєфу на протікання процесів та розподіл екологічних чинників. Розглянуто основні принципи екологічної класифікації елементів рельєфу, автоматизованого виділення форм та типів рельєфу на основі їхніх сигнатур, що виражаються через розподіл низки морфометричних величин та параметрів їхньої просторової мінливості.

Наведено огляд основних попередніх досліджень автора в області морфометричного аналізу поверхонь рельєфу кількох ділянок Українських Карпат, автоматизованої класифікації і сегментації рельєфу, аналізу зв'язків між морфометричними величинами та екологічними чинниками, характером наземного покриву та рослинності.

Ключові слова: екологічна геоморфометрія; топографічна поверхня; морфометричні величини; морфотоп; автоковаріограма; геометрична сигнатура.

\section{ECOLOGICAL GEOMORPHOLOGY, ITS SUBJECT, HISTORICAL ASPECTS AND METHODS}

Alexander Mkrtchian

Ivan Franko National University of Lviv

Abstract. Paper considers ecological geomorphometry as the scientific area aimed at the study of place and functions of terrain and modern morphogenetic processes in the functioning of other components of natural environment, ecosystems, and in shaping of the conditions for human activities, applying the methods of quantitative spatial analysis. Some terminological issues are considered, as well as a short history of geomorphometry, its main tasks and research methods. In particular, the methods of quantitative analysis of the structure of terrain surface are considered, namely -the detection of the spatial trends, of periodicity, and of the spatial autocorrelation. The capabilities of the method of autocovariogram building and analysis are shown for the purpose of the studies of terrain elements, forms and types, their automatic delineation and classification. The basics of ecologically grounded classification of morphometric variables are considered, as well as the principles of the delineation of complex morphometric variables (topographic ecological indices), which reflect the impact of terrain morphology on ecological processes and ecological factors distributions. The main principles of

СМкртчян Олександр, 2021. 
ecological classification of terrain elements are also considered, together with the automatic delineation of terrain forms and types on the basis of their geometric signatures, that are defined through the distribution of the set of morphometric variables and the parameters of their spatial variability.

Paper also reviews former studies by the author in the areas of morphometric analysis of the terrain surfaces of several study areas in Ukrainian Carpathians; the automatic terrain classification and segmentation; the analysis of the relationships between morphometric variables and ecological factors, the character of ground cover and the vegetation.

Key words: ecological geomorphometry; topographic surface; morphometric variables; morphotop, autocovariogram; geometric signature.

Вступ. Сучасний період розвитку більшості природничих наук характеризується двома вираженими тенденціями: зростанням ролі і значення кількісних методів досліджень (та пов'язаних з ними формальних підходів до наукового опису, аналізу і прогнозу), та екологізацією - поширенням екологічного підходу до досліджень традиційних об'єктів та предметів наукових дисциплін. Стосовно геоморфології це може знайти вияв у зростанні значення і ваги двох іiі галузей (напрямів): морфометрії - іiі характеризують як “галузь геоморфології, присвячена методам визначення числових характеристик форм рельєфу земної поверхні" (Мала гірнича енциклопедія, 2013) та екологічної геоморфології (напрям прикладної геоморфології, який вивчає рельєф, його походження, вік та еволюцію, процеси рельєфоутворення, їхню роль і функції у складній системі “природа - господарство - населення", аналізує прямі й зворотні зв'язки рельєфу з усіма компонентами навколишнього середовища 3 метою оптимізації умов життєдіяльності людини) (Павловська і Ковальчук, 2009).

Враховуючи, що перший з цих напрямів виокремлюють на основі специфіки методології та методів досліджень, тоді як другий - на основі їхньої мети та предмета, виглядає доцільним синтез обох зазначених напрямів у єдину (під)галузь, що займатиметься дослідженнями за допомогою методів кількісного просторового аналізу ролі рельєфу та процесів сучасного морфогенезу земної поверхні у функціонуванні інших складових довкілля, екосистем та формуванні умов життєдіяльності людини. Продуктом цього синтезу $є$ екологічна (гео)морфометрія - науковий напрям, який досліджує залежності між морфометричними характеристиками рельєфу та екологічними чинниками $\mathrm{i}$ процесами (Mkrtchian, 2020).

У попередній нашій англомовній праці (Mkrtchian, 2020) охарактеризовано місце екологічної геоморфометрії у сучасній геоморфології та у системі екологічних наук; iii базові поняття “атрибут рельєфу” (terrain attribute) та “топографічний індекс" (terrain index) та їхній зв'язок з поняттям екологічного чинника; поняття морфотопу та його зв'язок із поняттям біотопу; принципи i методи виділення морфотопів. Метою даної статті $\epsilon$ розвиток цих концептуальних напрацювань, а саме - розгляд питання обгрунтованості відповідного терміна для позначення досліджуваного наукового напряму; історії формування і розвитку сучасної геоморфометрії та її методичного наповнення; ілюстрація використання методу автокореляційного аналізу в аналізі особливостей морфометрії рельєфу фізико-географічних областей Українських Карпат як однієї з перспективних методик сучасної геоморфометрії. 
Методичні аспекти термінології. Насамперед необхідно прояснити деякі термінологічні моменти. В геоморфології знайшли широке застосування терміни "морфологія", "морфометрія" та низка похідних від них: "морфологічна класифікація", “морфометричні величини” тощо. Ці терміни мають цілком однозначну інтерпретацію в контексті геоморфології, проте в ширшому загальнонауковому контексті набувають багатозначності і невизначеності, адже етимологічно зводяться до загальнонаукової категорії “форми”. Наприклад,

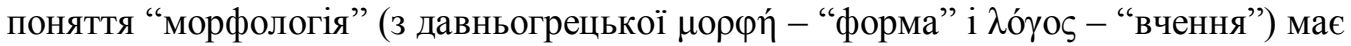
цілком відмінний предметний зміст, оскільки його використовують у низці різнорідних наукових дисциплін - від лінгвістики до клітинної біології та мінералогії. Натомість термін “геоморфометрія" чітко окреслює предметний зміст відповідного поняття, прив'язуючи його до земної поверхні та іiі форм. Англомовні дослідники у своїх працях користуються саме терміном “геоморфометрія" (geomorphometry) для позначення відповідної наукової дисципліни, у назвах наукових статей та монографій. 3 іншого боку, у відповідних наукових працях часто використовують терміни, похідні від “морфометрії”: “морфометричні величини”, “...змінні”, “...алгоритми” тощо. В цьому випадку зрозуміла перевага менш громіздкого терміна, предметний зміст якого цілком очевидний із контексту публікації. Отож, видається доцільнішим використовувати термін “геоморфометрія" (замість “морфометрія") для позначення відповідної наукової дисципліни, зокрема у назвах наукових праць, які можуть фігурувати поза межами геоморфологічного контексту у загальних літературних каталогах, індексах баз даних тощо. Тоді як спеціалізовані терміни геоморфометрії, предметний зміст яких зрозумілий 3 контексту, доцільно утворювати за допомогою приставки "морфо": напр., “морфометричні величини”, а не “геоморфометричні ...” тощо.

Поняття "екологія" і похідне від нього означення “екологічний” вважають одними 3 найневизначеніших у сучасній науці. Не вдаючись у дискусію щодо коректності тих чи інших інтерпретацій, у нашій праці використано найширше розуміння зазначеного поняття як такого, що інтерпретує земну поверхню як середовище життєдіяльності усіх елементів живої природи - від окремих організмів до їхніх угруповань та таксономічних одиниць, включаючи людину 3 іiї суспільними відносинами та господарською діяльністю.

У нашій публікації (Мкртчян, 2010) обгрунтовано виділення екологічної (гео)морфометрії як перспективного напряму еколого-геоморфологічних досліджень та визначено низку іï завдань, серед яких: 1) дослідження залежностей між морфометричними величинами та екологічними чинниками, розподілом окремих видів, характеристиками біоценозів та екосистем; 2) вивчення можливостей використання морфометричних величин як індикаторів екологічних чинників, процесів та характеристик $\mathrm{i}$ розробка методів морфометричної індикації; 3) обгрунтування комплексних морфометричних величин, що найповніше характеризуватимуть основні групи екологічних чинників та вдосконалення методики виділення ландшафтно-екологічних територіальних одиниць за цими чинниками.

Історія формування i розвитку сучасної геоморфометрії. Коротко розглянемо історію та сучасний стан досліджень в області геоморфометрії, зокрема 3 точки зору цілей та завдань, які постали перед екологічною 
геоморфологією, з наголосом на напрацюваннях західних дослідників, не надто відомих в Україні.

Перші фундаментальні розвідки у сфері геоморфометрії сягають 1970-х років. Слід згадати працю I. Еванса, в якій по-суті закладено основи теорії цієї наукової дисципліни, визначено загальні принципи виділення та класифікації морфометричних величин (Evans, 1972). Близькою за предметом $\epsilon$ праця Д. Марка (Mark, 1975); в подальших дослідженнях цього автора висвітлені питання автоматизованого виділення дренажних мереж шляхом аналізу морфометричних величин та питання аналізу фрактальної структури топографічних поверхонь (Mark, 1983), (Mark \& Aronson, 1984). У праці Р. Пайка та В. Роземи розкрито питання аналізу спектральної (періодичної) структури форм рельєфу та морфологічних систем (фактично - генетичних типів рельєфу), а також уперше введено поняття геометричної (топографічної) сигнатури рельєфу (Pike \& Rozema, 1975).

У наведених вище працях 1970-х років проаналізовано доволі складні теоретичні питання та зроблено низку цікавих та цінних висновків, які мають важливе значення для розвитку методології та вдосконалення методики геоморфометричних досліджень. Проте вони, здебільшого, не отримали подальшого розвитку і застосування в ті часи через відсутність необхідної кількості цифрових даних щодо морфології рельєфу та засобів аналізу таких даних. Проте “цифрова революція”, що розпочалась за два десятиліття опісля того, спричинила появу та поширення низки методів отримання, аналізу та обробки детальних цифрових морфометричних даних.

Зокрема, 2000 р протягом 11 днів виконали радарну зйомку поверхні Землі 3 борта Шаттла Endeavour. Отримана в результаті цифрова модель рельєфу (ЦМР) SRTM мала просторову роздільну здатність 1 арк-секунда (що приблизно відповідає 30 м на поверхні Землі). Початково дані такої роздільності були доступні тільки щодо території США, а для територій інших країн вони поширювалися зі зменшеною детальністю (3 арк-секунди, близько 90 м). Однак уже наприкінці 2014 року у відкритий доступ виклали дані 3 вихідною роздільністю (близько 30 м) практично для всієї поверхні земної суші між $60^{\circ}$ пн.ш. і $54^{\circ}$ пд.ш. (Jarvis et al., 2008).

Альтернативою цій ЦМР протягом декількох років слугувала ЦMP ASTER GDEM, отримана в результаті багатоканальної оптико-електронної стереоскопічної зйомки (першу версію викладено у вільний доступ 2009 р., дещо поліпшену другу - 2011 р). Ї̈̈ заявлена просторова роздільна здатність становить 1 арк-секунду (бл. 30 м), водночас іï якість $є$ дещо нижчою через наявність значної кількості аномалій і артефактів.

Новітні супутникові системи дистанційної зйомки Землі продукують стереозображення (зображення однієї й тієї ж ділянки земної поверхні під різними кутами) з просторовою роздільністю до 1 м і детальніше, обробка яких дає змогу отримувати високодетальні ЦМР. Останні (WorldDEM, Vricon) сьогодні доступні на комерційній основі: вартість становить десятки доларів за 1 $\mathrm{\kappa м}^{2}$, що обмежує використання цих даних в наукових та прикладних цілях.

Методи і алгоритми цифрової обробки та аналізу топографічних поверхонь набули значного поширення із розвитком ГІС-технологій. Алгоритми інтерполяції, переформатування, репроектування, фільтрації ЦМР, обрахунку за 
ними низки морфометричних величин, генерування дренажної мережі, тощо інтегровані як у спеціалізовані програмні пакети для аналізу топографічних поверхонь (LandSerf, DiGeM, тощо), так i в ГIC-програми загального призначення, що підтримують функції обробки та аналізу растрових даних (ArcMap, SAGA, GRASS, ERDAS IMAGINE, IDRISI тощо). Зазначимо, що алгоритми реалізації однакової функції у різних ГІС можуть відрізнятись, продукуючи відмінні результати навіть у разі їхнього застосування до тих самих вихідних даних. Окремо слід згадати $\mathrm{R}$ - популярну в науковому середовищі мову програмування та програмне середовище для статистичних обчислень, аналізу та представлення даних з відкритим кодом, що не належить до власне ГІС-програм, проте містить низку пакетів для роботи з геопросторовими даними.

Цей період розвитку геоморфометрії варто розпочати з праці Р. Пайка (Pike, 1988), де констатовано “безпрецедентні можливості", які надають цифрові гіпсометричні дані та комп’ютерні технології їхньої обробки для низки видів геоморфологічного аналізу. У дослідженні на основі розвитку концепції геометричної сигнатури та 75-ти морфометричних величин розроблено методику класифікації типів рельєфу для дослідної ділянки в Каліфорнії. В результаті виокремлено 7 типів, ранжованих у порядкову послідовність, від “дуже жорсткого" (very hard) через “проміжний” (intermediate) до “м'якого" (soft), причому для різних типів показане переважання тих або інших екзогенних морфодинамічних процесів (Pike, 1988). У пізнішій концептуальній праці цього дослідника (Pike, 1995), зокрема, наведено визначення геоморфометрії як "науки про кількісний аналіз (форми) земної поверхні”.

Із середини 1990-х років кількість досліджень 3 геоморфометрії суттєво зростає, i їх вдається можливим згрупувати довкола низки напрямів, які відрізняються предметною специфікою (детальну бібліографію не наводимо через її великий обсяг). Такими напрямами, зокрема, $є$ теоретичні дослідження рис та властивостей просторової структури гіпсометричних поверхонь, розробка підходів до дискретизації цих поверхонь (автоматизованого виділення елементів, форм та типів рельєфу методами класифікації та сегментації), вдосконалення методів автоматизованого виділення дренажних мереж за ЦМР, а також низка прикладних напрямів, зокрема - морфометрична індикація ризику розвитку процесів, насамперед таких, що становлять небезпеку чи спричиняють шкоду для людини та господарства (зсуви, осипища та обвали, лавини тощо).

Морфометричний аналіз структури гіпсометричної поверхні. Розглянемо, для прикладу, зміст досліджень, у яких методи морфометрії використовують для аналізу структури гіпсометричної поверхні. Складність цього завдання зумовлює різноманітність підходів та методів його вирішення, кожен з яких розкриває деякі часткові аспекти загальної проблеми. Загалом і просторову, і часову варіабельність будь-якого континуального феномену можна звести до трьох складових: регулярного тренду, періодичності та випадкових флуктуацій, які можуть корелювати між собою в просторі або в часі.

Для аналізу просторових трендів використовують метод трендових поверхонь, який дає змогу, з одного боку, виокремити найзагальніші великомасштабні риси просторової варіабельності, а з іншого - “віднявши” від складної вихідної гіпсометричної поверхні трендову, отримати дещо виразнішу картину середньо- і дрібномасштабної варіабельності. Виділені трендові 
поверхні можуть мати різний порядок: від першого (монотонний нахил у деякому напрямі) до другого (симетричний горб чи западина) i вищих, відображаючи тим самим різні рівні прояву неотектонічних процесів (локальні чи регіональні підняття або опускання) (Мкртчян і Чупило, 2008).

Просторова періодичність (ритмічність) гіпсометричної поверхні $€$ поширеним явищем, зокрема внаслідок специфіки тектонічних процесів i геологічної будови (складчастої чи насувної структури), або ж як прояв процесів самоорганізації гідролого-геоморфологічних процесів і систем, тобто періодичність у формуванні річкових меандр, терасоутворенні, чергуванні річкових долин і вододілів тощо (Мкртчян і Чупило, 2008), (Pike \& Rozema, 1975). До методів аналізу періодичності належить спектральний аналіз. Він полягає у розкладанні топографічної поверхні на сукупність хвиль (синусоїд та косинусоїд), амплітуда яких залежить від їхньої довжини. Як приклад регіонального геоморфологічного дослідження 3 використанням зазначеного методу можна назвати дослідження зі спектрального аналізу ЦМР СхідноЄвропейської рівнини, виконане в МДУ (Котлов і Пузаченко, 2006). У цьому дослідженні виділено ієрархічні рівні організації рельєфу та отримано карти структурних елементів, які виокремлено на кожному 3 цих рівнів. Автори припускають, що ієрархія структурних елементів рельєфу, виділена методом спектрального аналізу, є відображенням дії різних геодинамічних процесів, які мають характерні масштаби прояву.

Зрештою структуру нерегулярних флуктуацій топографічної поверхні, які демонструють автокорельованість, можна проаналізувати шляхом побудови автоковаріограм та автокорелограм - графіків відповідних функцій, які відображають зміну в коваріації чи кореляції значень відповідної величини зі збільшенням відстані між пунктами у просторі. Такі функції, зазвичай, мають характер спадних, проте на тлі загальної тенденції можна спостерігати окремі хвилі, виположення та перегини, які відображають структурні риси організації рельєфу.

У нашому дослідженні (Мкртчян i Чупило, 2008) проаналізовано топографічну поверхню ділянки центральної частини Українських Карпат (охоплює частини Вододільно-Верховинського та Полонинського хребтів i Вулканічних Карпат) на основі ЦМР з роздільною здатністю 76 м. На отриманій автокорелограмі чітко вирізнялись підвищення у межах відстаней 25-30 км, які відповідають характерним розмірам (ширині) головних тектонічних зон (Кросненської та Поркулецької), та перегини на менших відстанях, які, здбільшого, відповідають характерним розмірам різнорангових долинних форм рельєфу.

В одному 3 наших досліджень на основі аналізу ЦMP SRTM з роздільною здатністю близько 30 м розраховано автоковаріограми ділянок трьох фізикогеографічних областей Українських Карпат (Мкртчян, 2017) в межах басейну р. Чорна Тиса та околиць (рис. 1). 3 метою їхнього обрахунку створено спеціальний скрипт (функцію) мовою програмування R (Мкртчян, 2017), (R Core Team, 2017). Він приймає як вхід растровий шар у форматі RasterLayer, який можна отримати шляхом конвертації 3 інших растрових форматів засобами $\mathrm{R}$ (пакет raster). Автокореляцію послідовно розраховано для кожного лагу як суму квадратів різниці у величині між растром та ним же, зміщеним у просторі на цей лаг, 
поділену на кількість розрахованих значень (доданків). На виході отримуємо таблицю у форматі data frame 3 двох колонок: перша містить послідовні значення лагів, а друга - значення автоковаріації для цих лагів. Таблицю можна відтворити у формі відповідного графіка (автоковаріограми) графічними методами R (Мкртчян, 2017).

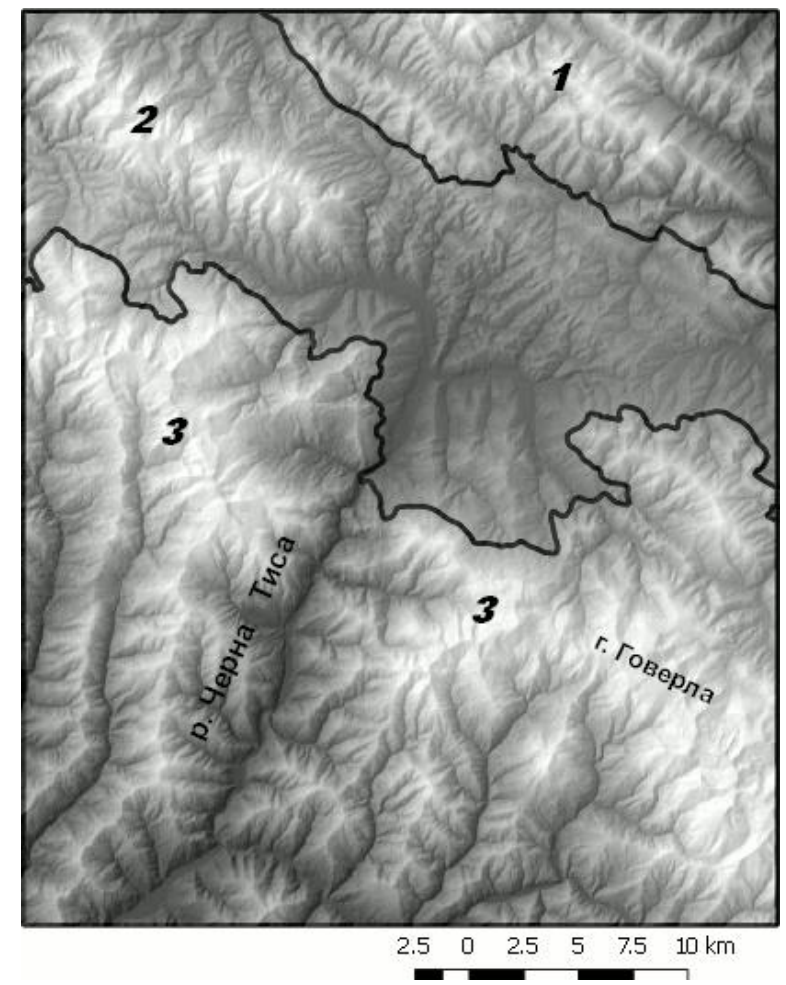

Рис .1. Ділянки трьох фізико-географічних областей Українських Карпат, для яких обраховано автоковаріограми абсолютних висот та крутості схилів: 1 - Зовнішньокарпатська область, 2 - Вододільно-Верховинська область, 3 - Полонинсько-Чорногірська область

Fig. 1. Areas of three physical geographical regions of Ukrainian Carpathians wherefor the autocovariograms for elevation and slope values have been calculated: $\mathbf{1}$ - Outer-Carpathians region, $\mathbf{2}$ - Watershed-Verhovyna region, 3 - PolonynyChornohora region

Автоковаріограми значень абсолютних висот та крутості схилів для трьох згаданих фізико-географічних областей наведені на рис. 2. Можна зауважити значні відмінності у ході автоковаріації цих двох характеристик, а також відмінності у ході автоковаріації окремих характеристик у межах різних фізикогеографічних областей. 
О. Мкртчян Зміст, історія формування та методи досліджень екологічної геоморфолометрії
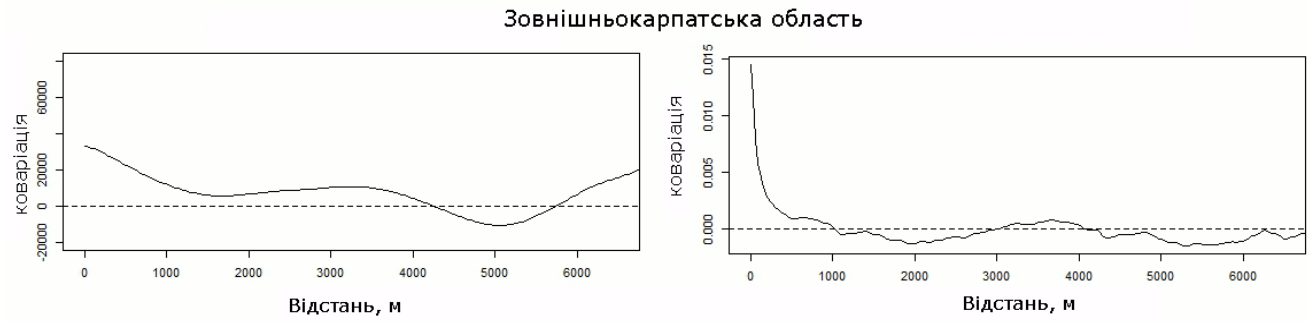

Вододільно-Верховинська область
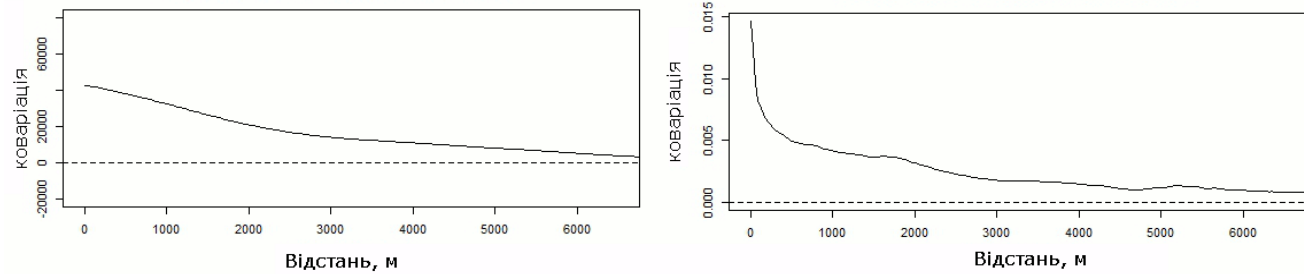

Полонинсько-Чорногірська область
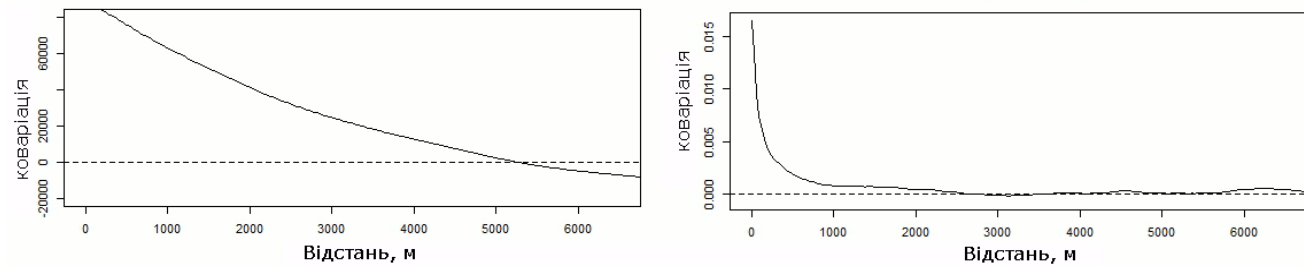

Рис. 2. Автоковаріограми значень абсолютних висот (ліворуч) та крутості схилів (праворуч) для ділянок трьох фізико-географічних областей Українських Карпат у межах басейну р. Чорна Тиса та околиць

Fig. 2. Autocovariograms of elevations (left) and slopes (right) for the areas of three physical geographical regions of Ukrainian Carpathians in the Black Tysza river basin and its vicinities

Автоковаріограма висот Зовнішньокарпатської області характеризується хвилястістю 3 періодом близько 3 км, що приблизно відповідає відстані між гребенями сусідніх хребтів. Для Вододільно-Верховинської області характерне повільне та плавне зменшення значень автоковаріації, а для ПолонинськоЧорногірської - високі початкові значення, які різко зменшуються зі зростанням відстаней. Автоковаріація крутості схилів характеризується різким спадом значень на відстанях 300-500 м (для першої і третьої областей практично обертаючись на 0 , і лише для “улоговинної” другої області - залишаючись додатною аж до відстаней в кілька км).

Виразна специфіка просторової варіабельності морфометричних величин у межах різних типів рельєфу та приурочених до них ландшафтних територіальних одиниць наводить на думку про можливість використання характеристик цієї варіабельності як діагностичних рис під час автоматизованого виокремлення та класифікації типів, форм та елементів рельєфу та відповідних щодо них природних комплексів. На відміну від простіших показників, таких, як функції розподілу висот, метод автоковаріограм краще відображає просторову структуру поверхні. Як ілюстрацію, порівняємо уявну монотонно нахилену поверхню 
(схил) із поверхнею, щільно розчленованою дрібними ерозійними формами: їхні функції розподілу висот можуть бути подібними, тоді як автоковаріограми будуть дуже відмінними.

Окрім наведених найпростіших морфометричних величин (абсолютна висота та похили поверхні), в геоморфометрії розглядають й низку інших, сукупність яких має якомога повніше описати форму земної поверхні. Складність завдання зумовлена тим, що предметом розгляду є не поверхня як така, а фізично та математично подвійна система "земна поверхня + геофізичне векторне поле" (Evans, 1972). До таких полів, зокрема, належать гравітаційне поле, поле сонячної радіації, поле вітрів. Будь-яке 3 них у кожній точці земної поверхні характеризується значенням інтенсивності та напрямом. Автор П. Шарий розробив систему базових морфометричних величин, визначених ним як “числова характеристика рельєфу, визначена в кожній точці карти"; морфометричні величини він розглядає як окремий випадок поняття морфометричної характеристики, які також включають такі характеристики, як, наприклад, площа та об'єм безстічної депресії: останні стосуються не конкретної точки, а цілої депресії (Шарый, 2006). Ця система налічує 18 морфометричних величин, які, здебільшого, $\epsilon$ різними різновидами кривизни. Ці величини поділено на поле-специфічні (характеризують взаємодію земної поверхні 3 деяким векторним полем) та на такі, що описують геометрію земної поверхні, ігноруючи поля, а також - на локальні (описують властивості обмеженого околу точки) та нелокальні (їхне визначення потребує розгляду протяжних ділянок поверхні). На основі співвідношень цих величин П. Шарий виокремив 12 простих морфометричних типів форм рельєфу.

Зазначений вище підхід до виокремлення морфометричних величин $\epsilon$ формальним і не бере до уваги екологічне значення цих величин, тобто наявність та вираженість їхнього зв'язку 3 екологічними факторами, чинниками грунтотворення, критеріями сприятливості земельної ділянки для певних видів антропогенної діяльності. У своїй статті П. Шарий згадує низку аспектів екологічних впливів рельєфу: вплив на розподіл поверхневого стоку, ерозійноакумулятивні процеси, термічний режим схилів, наводить огляд праць, у яких проаналізовано вплив морфометричних величин на характер рослинного покриву та продуктивність сільськогосподарських культур (Шарый, 2006). Проте, у його дослідженнях відсутній детальний аналіз екологічного змісту запропонованих морфометричних величин.

Екологічне значення морфометричних величин пов'язане 3 тим, наскільки точно вони відображають процеси і явища, які пов'язані 3 рельєфом та впливають на розподіл екологічних чинників на земній поверхні. Так, добре відомим є вплив цих величин на кліматичні характеристики. Цей вплив може проявлятись по-різному на різних масштабних рівнях: якщо на більших рівнях визначальне значення мають абсолютна висота місцевості та орієнтація повідношенню до панівних напрямків руху повітряних мас, то на менших рівнях на перший план виходять солярна експозиція, яка зумовлює неоднакове нагрівання схилів, та особливості морфометрії, які сприяють стіканню холодного повітря вночі та формуванню термічних інверсій (Mkrtchian \& Kovalchuk, 2019).

Вплив морфометричних величин на розподіл зволоженості безпосередньо зумовлений стіканням води у пониження рельєфу під дією сили тяжіння. Рівень 
зволоженості визначається дренажною площею, 3 якої надходить стік на одиницю замикаючого контуру (нелокальна морфометрична величина), а також похилом (крутістю) поверхні та модулем його першої похідної (профільною кривизною), від якої залежить, чи буде вода стікати далі вниз по схилу, або ж чи переважатиме застій води і ії просочування в нижні шари грунту.

Вплив морфометричних величин на трофність грунту є найбільш складним через опосередкованість цього впливу ерозійними процесами, які, крім морфометрії рельєфу, зазнають впливу низки інших чинників. Проте, з цими величинами можна пов'язати цілу низку фізико-хімічних властивостей грунтів: потужність, гумусованість, щебенистість, кислотність, тощо.

У змістовних дослідженнях більшого значення набувають складені або похідні морфометричні величини, які визначають у процесі аналізу механізмів конкретних процесів переносу енергії та речовини. Одним 3 прикладів $\epsilon$ складений топографічний індекс (TWI, топографічний індекс вологості), запропонований I. Муром та П. Гесслером (Moore et al., 1993). Цей індекс відображає врівноважену величину надходження вологи внаслідок піi латерального перерозподілу на схилах та визначає положення у ландшафтній катені. Місцеположення 3 високими значеннями цього індексу, зазвичай, характеризуються нагромадженням схилової вологи, сирими і вологими умовами місцезростання рослин, поширеністю явищ оглеєння грунту, тоді як низькі значення відповідають добре дренованим місцеположенням. Наше дослідження дало змогу, зокрема, встановити залежність між значеннями цього індексу та формулою деревостану, визначеною у 77-ми пунктах дослідної ділянки, вкритої умовно-корінними та псевдокорінними деревостанами (Мкртчян, 2014).

Подібні за формою вирази використовують для аналізу процесів площинної ерозії грунтів. Оскільки на перебіг цих процесів загалом впливають не лише морфологія рельєфу, а й властивості грунтів і підстилаючих порід, характер і стан рослинного покриву та деякі інші чинники, які, подібно до морфометричних величин, можуть варіювати у просторі в межах території досліджень, у загальному випадку адекватний опис цих процесів потребує побудови відповідної моделі. Проте просторова варіабельність цих процесів, передусім на невеликому (локальному) масштабному рівні, часто визначається, здебільшого, топографічним чинником, отож просторовий опис і картування наслідків цих процесів, з точки зору формування ними екологічних умов і чинників, можна у першому наближенні виконувати на основі відповідних морфометричних величин (індексів).

Аналогічно, відповідні морфометричні величини можна використовувати для моделювання локальних відмінностей в умовах освітлення та в термічному режимі. У першому випадку моделюють розподіл надходження сонячної радіації на схили різної крутості та експозиції, інтегруючи його за деякий період часу, наприклад - вегетаційний період. Залежно від складності в таких моделях можна враховувати ефекти затінення та атмосферного поглинання радіації за низької висоти сонця над горизонтом, відмінності в розподілі надходження прямої та розсіяної радіації, поглинання хмарами, поглинання та випромінювання поверхнею довгохвильової радіації, притаманні місцевому клімату річні та добові зміни у хмарності та прозорості атмосфери. Відмінності у термічному режимі, окрім пов'язаних 3 експозиційними відмінностями в освітленості, 
можуть виникати внаслідок особливостей локальної циркуляції повітряних мас, що регулюються топографією, а отже - можуть бути описаними відповідними морфометричними змінними.

Як основу екологічно орієнтованої систематизації морфометричних величин нами (Мкртчян, 2010) запропоновано в використовувати три групи прямих та ресурсних екологічних факторів (градієнтів): 1) такі, що описують перерозподіл сонячної та теплової енергії; 2) такі, що описують перерозподіл вологи під дією сили тяжіння; 3) такі, що описують перерозподіл твердої речовини під дією гравітації. Відповідно до них визначають морфометричні (топографо-екологічні) індекси, які можна обрахувати за відповідними похідними від ЦМР растровими шарами (рис. 3).

Прямі екологічні фактори

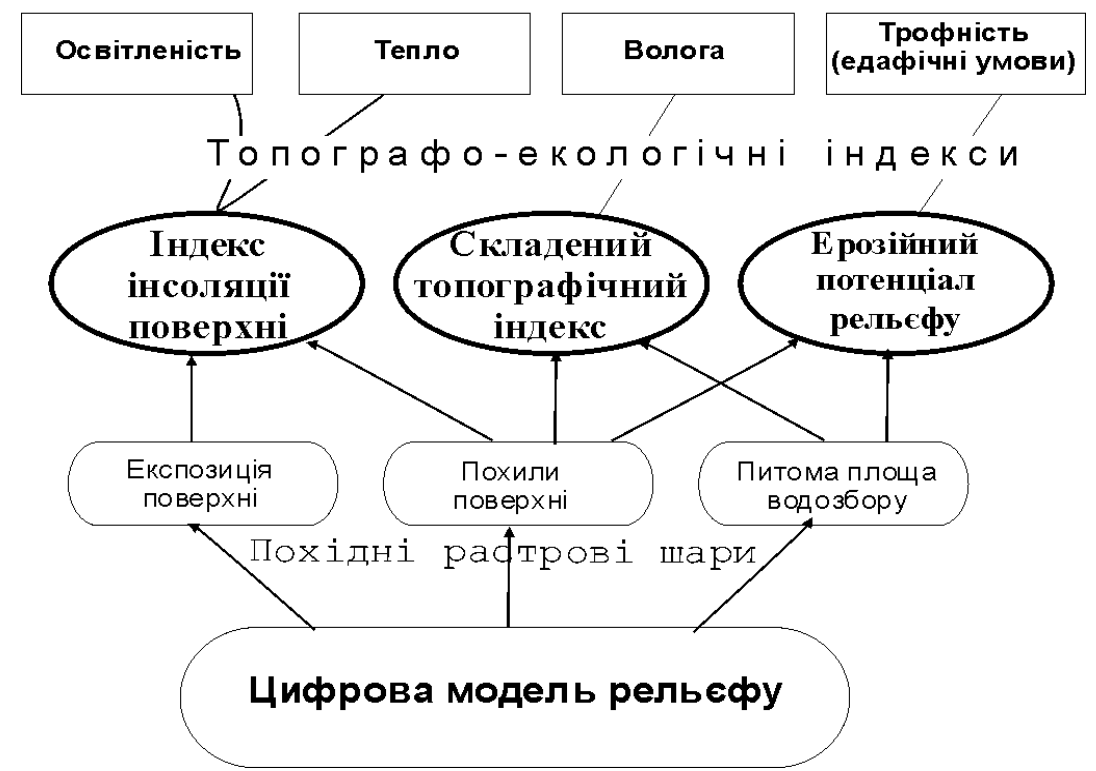

Рис. 3. Зв'язок між морфометричними індексами та групами екологічних факторів.

Fig. 3. Relationship between morphometric indices and groups of ecological factors

Одна 3 наших праць (Mkrtchian, 2013) містить дослідження зв'язків між низкою морфометричних величин, зокрема тих, що відповідають зазначеним групам екологічних факторів, та головними компонентами мультиканального геозображення LANDSAT $7 \mathrm{ETM}+$, які відображають характер наземного покриву та рослинності, для ділянки розмірами 90 на 70 км, розміщеної в центральній частині Українських Карпат. Метод канонічного кореляційного аналізу дав змогу виокремити три канонічні корені, які описують незалежні компоненти їхньої спільної просторової варіабельності. Перший, найбільш значущий корінь загалом характеризує висотний градієнт у зміні екологічних умов, другий - градієнт від затінених крутих еродованих схилів до пласких добре освітлених поверхонь, третій - певною мірою описує макроекспозиційні 
відмінності між місцеположеннями північно-східного та південно-західного макросхилів (Mkrtchian, 2013).

Однією 3 переваг формально визначених морфометричних величин та індексів $€$ можливість створення на їхній основі формалізованих методик автоматизованої, об'єктивної та однозначної класифікації і сегментації рельєфу. Зокрема, здійснена нами автоматична екологічна класифікація елементів рельєфу на основі параметрів, які характеризують надходження сонячної радіації, перерозподіл вологи та грунтову ерозію, дала змогу виокремити 5 класифікаційних одиниць (морфотопів). Водночас виявлено достовірний статистичний зв'язок між останніми та значеннями рясності рослин (Ковальчук та Мкртчян, 2008).

У зазначених випадках йдеться, передусім, про екологічну класифікацію елементів рельєфу різного порядку. Виокремлені при цьому різнопорядкові територіальні одиниці $€$ морфотопами. В нашій праці (Мкртчян, 2004) морфотопи визначені як виділені за ознаками морфології земної поверхні та достатньою мірою екологічно однорідні територіальні одиниці, які, виходячи 3 характеристик території, цілей дослідження, наявних даних та можливостей їхнього збору та обробки, недоцільно поділяти за геоморфогенно зумовленими внутрішніми відмінностями у природних умовах на дрібніші територіальні складові. Проте екологічні ознаки можуть бути поставлені у відповідність не лише елементам, а й формам рельєфу та його типам. Автоматизоване виділення форм та типів рельєфу має спиратись на поняття сигнатури, визначене Р. Енцманом як “набір вимірювань, достатній для однозначної ідентифікації об”єкта або групи об'єктів” (Enzmann, 1966). У геоморфометрію концепція сигнатури прийшла зі сфери аналізу дистанційних зображень, де, зокрема, виділення спектральних сигнатур класів $\epsilon$ складовою керованої класифікації мультиканальних геозображень. Геометричні сигнатури визначено Р. Пайком як "набір вимірювань, який описує форму земної поверхні достатньою мірою для того, щоби мати змогу виділити геоморфологічно відмінний ландшафт" (Pike, 1986). У випадку просторово протяжних об'єктів і територій такі сигнатури можуть виражатись не лише через середні значення та варіабельність низки морфометричних величин, а й через характер їхньої просторової мінливості у межах окремих форм та типів рельєфу. Цю мінливість можна охарактеризувати параметрами відповідних трендових поверхонь, спектральних перетворень (у випадку просторової періодичності) або ж параметрами функції автоковаріації (автоковаріограми).

Висновки. Екологічна (гео)морфометрія - науковий напрям, який досліджує залежності між морфометричними характеристиками рельєфу та екологічними факторами i процесами. Ї̈̈ завданням $€$ дослідження залежностей між морфометричними величинами та екологічними чинниками, розробка методів морфометричної індикації характеристик біоценозів та екосистем, обгрунтування комплексних морфометричних величин, що найповніше характеризуватимуть основні групи екологічних чинників. Розвиткові геоморфометрії, в основу якої покладено кількісний аналіз морфометричних характеристик рельєфу, суттєво сприяла "цифрова революція", що зумовила появу та поширення низки ефективних методів отримання, аналізу та обробки детальних цифрових морфометричних даних. 
Просторову варіабельність континуальної топографічної поверхні можна звести до трьох складових: регулярного тренду, періодичності та випадкових флуктуацій, які потребують спеціальних методів аналізу. Зокрема, до методів аналізу періодичності належить спектральний аналіз, а структуру нерегулярних флуктуацій топографічної поверхні, які демонструють автокорельованість, можна проаналізувати шляхом побудови автоковаріограм та автокорелограм. Екологічне значення морфометричних величин пов'язане $з$ тим, наскільки точно вони відображають процеси і явища, які стосуються рельєфу та впливають на розподіл екологічних чинників на земній поверхні. У змістовних дослідженнях більшого значення набувають складені або похідні морфометричні величини, які визначають в процесі аналізу механізмів конкретних процесів переносу енергії та речовини.

\section{СПИСОК ВИКОРИСТАНОЇ ЛІТЕРАТУРИ}

Геоморфологія: терміни й поняття (коментар) : навч. посібник [для студ. вищ. навч. закл.] / Павловська Т. С. ; за ред. проф. І. П. Ковальчука. - Луцьк : Волин. нац. ун-т ім. Лесі Українки, 2009. - 284 с.

Ковальчук I. Автоматизована екологічна класифікація елементів рельєфу та ii застосування для вивчення річково-долинних ландшафтів / І. Ковальчук, О. Мкртчян // Вісник Львівс. ун-ту. Серія геогр. -2008. - Вип. 35. - С.159-164.

Котлов И. П. Структура рельефа Русской равнины как ландшафтообразующего фактора / И. П. Котлов, Ю. Г. Пузаченко // Ландшафтное планирование: общие основания, методология, технология. Труды Международной школыконференции "Ландшафтное планирование". - Москва : МГУ, 2006. - С. 166172.

Мала гірнича енциклопедія. Т. III / за редакцією В. С. Білецького. - Донецьк : Східний видавничий дім, 2013. - 644 с.

Мкртчян А. С. Анализ автоковариационной структуры характеристик низкогорного ландшафта / А. С. Мкртчян // Ландшафтоведение: теория, методы, ландшафтно-экологическое обеспечение природопользования и устойчивого развития : материалы XII Международной ландшафтной конференции, Тюмень-Тобольск, 22-25 августа 2017 г. : в 3 т. / отв. ред. чл.кор. РАН К.Н. Дьяконов. - Тюмень : Издательство Тюменского государственного университета, 2017. - Т. 1. - С. 98 - 103.

Мкртчян О. Автоматизоване ландшафтно-екологічне районування території методами кластеризації і сегментації / О. Мкртчян // Вісник Львів. ун-ту. Сер. геогр. - 2014. - Вип. 4. - С.177-184.

Мкртчян О. Моделювання розподілу ландшафтно-екологічних характеристик 3 використанням топографічних індексів / О. Мкртчян // Вісн. Львів. ун-ту. Серія геогр. - 2006. - Вип. 33. - С. 261-267.

Мкртчян О. Морфотопи як територіальні одиниці картування та оцінки природних умов / О. Мкртчян // Наук. записки Тернопільського національного педагог. ун-ту. Сер. геогр. - 2004. - № 3. - С. 181-187.

Мкртчян О. С. Екологічна морфометрія як перспективний напрямок екологогеоморфологічних досліджень / О. Мкртчян // Фізична географія i геоморфологія. - 2010. - Вип. 1(58). - С.131-136. 
Мкртчян О. С. Геоінформаційний аналіз просторових зв'язків морфометрії рельєфу з геологічною структурою (на прикладі західної частини ВододільноВерховинських i Полонинських Карпат) / О. С. Мкртчян, Г. Р. Чупило (Байрак) // Теоретичні та прикладні аспекти геоінформатики : збірник наук. праць. - Київ, 2008. - С. 250-261.

Національний атлас України / НАН України, Інститут географії, Державна служба геодезії, картографії та кадастру ; гол. ред. Л. Г. Руденко. - Київ : Картографія, 2007. - 435 с.

Шарый П. А. Геоморфометрия в науках о земле и экологии, обзор методов и приложений / П. А. Шарый // Известия Самарского научного центра РАН. 2006. - № 8(2). - C. 458-473.

Enzmann R. D. Introduction to the Section on Signatures, in Planetology and Space Mission Planning / R. D. Enzmann // Ann. New York Acad. Sci. - 1966. - V. 140, Article 2. - P. 154-156.

Evans I. S. General Geomorphometry, Derivatives of Altitude, and Descriptive Statistics / R. J. Chorley (Ed.), Spatial Analysis in Geomorphology. - London : Methuen, 1972. - P. 17-90.

Hengl T., Reuter H. I., eds. Geomorphometry: concepts, software, applications / T. Hengl, H. I. Reuter. - Amsterdam : Elsevier, 2009. - 765 p.

Jarvis A., Reuter H. I., Nelson A., Guevara E. Hole-filled seamless SRTM data V4. International Centre for Tropical Agriculture (CIAT). - 2008. Retrieved from : https://www2.jpl.nasa.gov/srtm/

Mark D. M. Geomorphometric parameters: a review and classification / D. M. Mark // Geografiska Annaler. - 1975. - Vol. 57 A. - P. 165-177.

Mark D. M. Relations between field-surveyed channel networks and map-based geomorphometric measures / D. M. Mark // Annals of the Association of American Geographers. - 1983. - Vol. 73. - P. 358-272.

Mark D. M. Scale-Dependent fractal dimensions of topographic surfaces: An empirical investigation with applications in geomorphology and computer mapping/ D. M. Mark, P. B. Aronson // Mathematical Geology. - 1984. - № 16 (7). - P. 671683.

Mkrtchian A. Assessment of spatial significance and error of correlation coefficients calculated for spatially distributed data accounting for spatial autocorrelation / A. Mkrtchian // ГІС-ФОРУМ-2017: Збірник матеріалів конференції (Харків, 22-24 лютого 2017 р.). - Харків : ХНУ: Смугаста типографія, 2017. - Вип. 1. C. 18-21. URL : http://gis-forum.org.ua/files/2017/journal_2017.pdf

Mkrtchian A. Features of ecological geomorphometry as a prospective field of study, its main concepts and methods / A. Mkrtchian // Проблеми геоморфології i палеогеографії Українських Карпат і прилеглих територій : Збірник наук. праць. - 2020. - Вип. 1(11). - С. 140-155. https://doi.org/10.30970/gpc.2020.1.3205

Mkrtchian A. The relations between land surface morphometry and spectral characteristics of ecosystems in the Ukrainian Carpathians / A. Mkrtchian // Ekológia (Bratislava). - 2013. - Vol. 32, No. 1. - P. 87 - 94.

Mkrtchian A. Terrain morphology as factor of local temperatures distribution in Ukrainian Carpathians / A. Mkrtchian, I. Kovalchuk // Проблеми геоморфології і 
палеогеографії Українських Карпат і прилеглих територій: Збірн. наук. праць. - 2019. - Вип. 1(9). - С. 62-72. https://doi.org/10.30970/gpc.2019.1.2803

Moore I. D. Soil attribute prediction using terrain analysis / I. D. Moore, P. E. Gessler, G. A. Nielsen, G. A. Peterson // Soil Science Society of America Journal. - 1993. - Vol. 57. - P. 443-452.

Pike R. J. Geometric Signatures of Intermediate-Scale Topography [abs.] / R. J. Pike // Geol. Soc. Amer. Abst. Prog. - 1986. - V. 18., no. 2. - P. 171.

Pike R. J. The geometric signature: quantifying landslide terrain types from digital elevation models / R. J. Pike // Mathematical Geology. - 1988. - Vol. 20, No. 5. P. 491-511.

Pike R. J. Spectral Analysis of Landforms / R. J. Pike, W. J. Rozema // Ann. Assoc. Amer. Geog. - 1975. - V. 65. - P. 499-516.

Pike R.J. Geomorphometry - progress, practice, and prospect / R. J. Pike // Z. Geomorph. Suppl.-Bd. - 1995. - N 101. - P. 221-238.

R Core Team. R: A language and environment for statistical computing., - Vienna, Austria : R Foundation for Statistical Computing, 2017. Retrieved from : https://www.R-project.org/.

\section{REFERENCES}

Kovalchuk, I., Mkrtchian, O. (2008). Avtomatyzovana ecolohichna klassifikaciya elementiv reliefu ta yiyi zastosuvannya dlya vyvchennya richkovo-dolynnyx landshaftiv [Automatic ecological relief elements classification and its application for study of river-valley landscapes]. In Visnyk of Lviv university. Geography, 35, 159-164. (In Ukrainian).

Kotlov, I. P., Puzachenko, Yu. G. (2006). Struktura reliefa Russkoj ravniny kak landshaftoobrazuyushhego faktora [Structure of Russian plain relief as a landscapeforming factor]. In Proceedings of the Int. school-conference "Landscape planning”. Moscow : MSU, 166-172. (In Russian).

Mala girnycha encyklopediya [Small mining encyclopedia]. Vol. 3. (ed. V. S. Biletskyi). (2013). Donetsk : Eastern publ. house. (In Ukrainian).

Mkrtchian, A. S. (2017). Analiz avtokovariacionnoj struktury harakteristik nizkogornogo landshafta [Analysis of autocovariation structure of low-mountain landscape]. In Proceedings of the XII Int. landscape conf. Vol. 1. Tiumen : Tiumen state univ., 98-103. (In Russian).

Mkrtchian, O. (2014). Avtomatyzovane landshaftno-ekologichne rajonuvannya terytoriyi metodamy klasteryzaciyi i segmentaciyi [Automatic landscape-ecological regionalization by the application of clustering and segmentation]. In Visnyk of Lviv university. Geography, 4, 177-184. (In Ukrainian).

Mkrtchian, O. (2006). Modelyuvannya rozpodilu landshaftno-ekologichnyx xarakterystyk z vykorystannyam topografichnyx indeksiv [Modeling of landscapeecological characteristics distribution by means of topographic indices]. In Visnyk of Lviv university. Geography, 33, 261-267. (In Ukrainian).

Mkrtchian, O. (2004). Morfotopy yak terytorialni odynyci kartuvannya ta ocinky pryrodnyx umov [Morphotopes as areal units of the mapping and evaluation of natural resources]. In Scientific notes of Volodymyr Hnatiuk Ternopil national pedagogical university. Series: Geogr., 3, 181-187. (In Ukrainian). 
Mkrtchian, O. (2010). Ekologichna morfometriya yak perspektyvnyj napryamok ekologo-geomorfologichnyx doslidzhen [Ecological morphometry as a perspective direction of ecological-geomorphological researches]. In Physical geography and geomorphology, 1(58), 131-136. (In Ukrainian).

Mkrtchian, O. S., Chupylo (Bayrak), G. R. (2008). Geoinformacijnyj analiz prostorovyx zvyazkiv morfometriyi relyefu $\mathrm{z}$ geologichnoyu strukturoyu (na prykladi zaxidnoyi chastyny Vododilno-Verxovynskyx i Polonynskyx Karpat) [GIS analysis of spatial relations between terrain morphometry and geological structure (on example of the western part of Watershed-Verhovyna and Polonyny Carpathians]. In Theoretical and applied aspects of geoinformatics. Kyiv, 250-261. (In Ukrainian).

Nacionalnyj atlas Ukrayiny [National atlas of Ukraine]. (2007). By NAN of Ukraine, Institute of Geography, State Geodesy, Cartography and Cadaster service. (ed. L. G. Rudenko). Kyiv : "Cartography". (In Ukrainian).

Pavlovska, T. S., Kovalchuk, I. P. (2009) Geomorphologiya: terminy $j$ poniattia (komentar) [Geomorphology: terms and concepts (comments)]. Textbook. Lutsk: Volyn Lesia Ukraïnka national university. (In Ukrainian).

Shary P. A. (2006). Geomorfometriya v naukah o zemle i ekologii, obzor metodov i prilozhenij [Geomorphometry in the Earth sciences and ecology: review of methods and applications]. In News of the RAS Samara scientific center, 8(2), 458-473. (In Russian).

Enzmann, R. D. (1966). Introduction to the Section on Signatures. In Planetology and Space Mission Planning. Ann. New York Acad. Sci.,140(2), 154-156.

Evans, I. S. (1972). General Geomorphometry, Derivatives of Altitude, and Descriptive Statistics. Chorley, R. J. (Ed.) In Spatial Analysis in Geomorphology. London : Methuen, 1972, 17-90.

Hengl, T., Reuter, H. I. (Eds.) Geomorphometry: Concepts, Software, Applications (2008). In Developments in Soil Science, 33.

Jarvis, A., Reuter, H. I., Nelson, A., Guevara, E. (2008) Hole-filled seamless SRTM data V4. International Centre for Tropical Agriculture (CIAT). URL: http://srtm.csi.cgiar.org

Mark, D. M. (1975). Geomorphometric parameters: a review and classification. In Geografiska Annaler, 57 A, 165-177.

Mark, D. M. (1983). Relations between field-surveyed channel networks and mapbased geomorphometric measures. In Annals of the Association of American Geographers, 73, 358-272.

Mark, D. M., Aronson, P. B. (1984). Scale-Dependent fractal dimensions of topographic surfaces: An empirical investigation with applications in geomorphology and computer mapping. In Mathematical Geology, 16 (7), 671-683.

Mkrtchian, A. (2017). Assessment of spatial significance and error of correlation coefficients calculated for spatially distributed data accounting for spatial autocorrelation. In Proceedings of conf. "GIS-Forum-2017", Iss. 1. Kharkiv : Smuhasta publishing, 18-21. http://gis-forum.org.ua/files/2017/journal 2017.pdf

Mkrtchian, A. (2020). Features of ecological geomorphometry as a prospective field of study, its main concepts and methods. In Problems of geomorphology and paleogeography of the Ukrainian Carpathians and adjacent areas, 1(11), 140-155. https://doi.org/10.30970/gpc.2020.1.3205 
Mkrtchian, A. (2013). The relations between land surface morphometry and spectral characteristics of ecosystems in the Ukrainian Carpathians. In Ekológia (Bratislava), 32(1), 87-94.

Mkrtchian, A., Kovalchuk, I. (2019). Terrain morphology as factor of local temperatures distribution in Ukrainian Carpathians. In Problems of geomorphology and paleogeography of the Ukrainian Carpathians and adjacent areas, 1(9), 62-72.

Moore, I. D., Gessler, P. E., Nielsen, G. A., Peterson, G. A. (1993). Soil attribute prediction using terrain analysis. In Soil Science Society of America Journal, 57, 443-452.

Pike, R. J. (1986). Geometric Signatures of Intermediate-Scale Topography. In Geol. Soc. Amer. Abst. Prog, 18, no. 2, 171.

Pike, R. J. (1988). The geometric signature: quantifying landslide terrain types from digital elevation models. In Mathematical Geology, 20(5), 491-511.

Pike, R. J., Rozema, W. J. (1975). Spectral Analysis of Landforms. In Ann. Assoc. Amer. Geog., 65, 499-516.

Pike, R. J. (1995). Geomorphometry - progress, practice, and prospect. In Z. Geomorph. Suppl.-Bd., 101, 221-238.

$\mathrm{R}$ Core Team. (2017). R: A language and environment for statistical computing. Vienna, Austria : R Foundation for Statistical Computing. Retrieved from: https://www.R-project.org/.

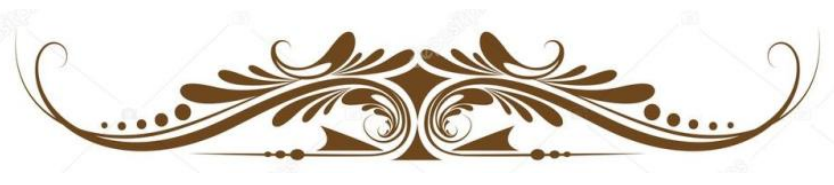

